\title{
Can 'Sufficiency' reconcile social and environmental goals? A Q-methodological analysis of German housing policy
}

\author{
Katharina Bohnenberger ${ }^{1}$ (D)
}

Received: 29 October 2019 / Accepted: 18 June 2020 / Published online: 18 July 2020

(c) The Author(s) 2020

\begin{abstract}
In housing policy, social and environmental targets often appear to be in conflict. This article examines to which degree the rising sustainability strategy 'sufficiency' has the potential to overcome this alleged trade-off between social and environmental goals in Germany. The positions of relevant stakeholders from social, environmental, and housing interest groups in Germany on housing policy are analysed by use of Q-methodology. Four distinct positions towards sufficiency-oriented housing policy are identified. The results show under which conditions sufficiency is a promising strategy to reconcile declared social and environmental targets in German housing policy. If pursued by a coalition of housing organizations and environmental interest groups, sufficiency has the potential of becoming a major paradigm in housing policy in Germany and beyond.
\end{abstract}

Keywords Housing policy · Q-method analysis · Sufficiency concept $\cdot$ Sustainable housing · Germany

\section{Introduction: The alleged trade-off between social and environmental goals in housing}

Environmental protection and social well-being seem to be at odds in housing policy. On the one hand, more living space, better equipment und higher room temperatures are associated with better living standards (Sovacool 2015), the detached family house has for many decades been the desired living form and currently, and even in countries like Germany with a stagnating population, new construction is demanded to ensure access to and affordability of housing. The associated building and construction policies have negative impacts on three environmental parameters: firstly, land use through new buildings, including the energy-consumption and emissions of the occupants' transport; secondly, material and energy consumption of construction activity itself; and thirdly, greenhouse gas emissions from the energy-use for the operation of existing buildings. On the other hand, many environmental policies in the housing sector were criticized as counteracting social

Katharina Bohnenberger

katharina.bohnenberger@uni-due.de

1 Institute for Socio-Economics, University of Duisburg-Essen, Lotharstr. 65, 47057 Duisburg, Germany 
goals such as affordable housing, for example by raising housing costs through mandatory and costly energy-efficient retrofitting. The conflicts arising from these measures suggest a trade-off between the environmental objectives of climate protection, resource protection and reduction of land use, and the social goals of adequate and affordable housing for everybody.

Sustainable Housing is a growing research field that seeks to bridge this gap. Being shaped by the Brundtland Report on sustainable development (WCED 1987), the research field experienced its first rise with green housing projects in the 1990s. However, at that time sustainable housing was self-evaluated as lacking theoretical foundation (Brown and Bhatti 2003). In the literature, sustainable housing is frequently interpreted as a strategy to balance the three dimensions of ecological, social and economic sustainability (Smets and van Lindert 2016). While the connection of ecological and economic indicators is well researched in housing studies (Winston and Pareja Eastaway 2008), the social dimension of sustainability is still under development and lacks integration with the economic and environmental dimension (Dempsey et al. 2011; Eizenberg and Jabareen 2017). This is surprising given the long tradition of the discipline in dealing with multifaceted requirements but can be explained by a perceived trade-off between social progress and environmental issues (Dixon and Woodcraft 2013). Taking this into account, the first sufficiency-based concepts of sustainable housing emerged and interpreted sustainable housing as housing that respects the upper limits of ecological carrying capacity and the lower limits of meeting basic human needs (Choguill 2007). Promoted by the inclusion of several housing related goals in the Agenda 2030 (e.g. SDG11.1 by 2030, ensure access for all to adequate, safe and affordable housing housing (...); SDG11.6 by 2030, reduce the adverse per capita environmental impact of cities (...)), sustainable housing is currently experiencing a second rise with recent research focussing on the integration of social and environmental goals in housing policy (Xue 2012; Muñiz et al. 2013; Bouzarovski et al. 2018; Poruschi and Ambrey 2018; Wickes et al. 2019; Chan and Adabre 2019; Hagbert and Malmqvist 2019; Rufat and Marcińczak 2020). Neighbouring disciplines, particularly energy and environmental studies, can contribute in this respect and are already influencing the development of the research field.

Until now, the main approaches in environmental policy, also when it comes to housing, have been the sustainability strategies 'efficiency' and 'consistency'. Efficiency seeks to increase the rate of output to input of materials and energy, i.e. a higher resource productivity, and consistency looks for eco-friendly technologies, which use materials and services of ecosystems without destroying them (Huber 2000a). Efficiency and consistency strategies face a number of limitations (Schäpke and Rauschmayer 2014; Korhonen et al. 2018; Parrique et al. 2019). With ecological problems becoming more pressing due to lingering implementation of environmental policies, efficiency and consistency are less likely to suffice for combating ecological problems. Therefore awareness and advocacy of policy proposals which target environmental goals in housing using 'sufficiency' approaches is growing (e.g. Clune et al. 2012; Huebner and Shipworth 2017; Sandberg 2018; Shove 2018; Cohen 2019; McKinlay et al. 2019; Lorek and Spangenberg 2019; Sorrell et al. 2020). The threefold distinction between efficiency, consistency and sufficiency is established in sustainability research and was applied to a number of research fields such as transport and nutrition (Huber 2000b; Muller and Schrader 2017; Samadi et al. 2017).

The key goal of sufficiency policy in housing is the reduction of demand for new construction and housing space in general (Lorek and Spangenberg 2019). From a sufficiency perspective and in distinction to efficiency and consistency, the amount of housing space 
per person is hence a central unit in meeting environmental targets. In Germany, for example, the available housing space per person more than doubled within 50 years, from $22.3 \mathrm{~m}^{2}$ in 1965 to $46.2 \mathrm{~m}^{2}$ in 2015 (Rahlf 2015). These developments cancel out advances that were reached by higher energy-efficiency and better use of renewable energies in the housing sector (Wilson and Boehland 2008; Stephan and Crawford 2016; Viggers et al. 2017). More housing space means using both more land and more resources for construction and maintenance of the building while more living space per person consumes, all else being equal, more energy during operation, particularly for heating and ventilation (Krausmann et al. 2020; Röck et al. 2020). A recent study in Nature Energy even argued that "house size is the largest determinant of domestic energy consumption" and hence globally growing floor space per capita is a problematic trend (Ellsworth-Krebs 2020). The author of the study affirms the considerations of previous research that sufficiency policy could reverse this trend and thereby complement ecological goals where previous approaches have fallen short. Furthermore, there are also credible theoretical considerations that sufficiency policy is positively contributing to social goals such as availability, adequateness and affordability of housing (see Sect. 2). This suggests the hypothesis that sufficiency could dissolve conflicts between social and environmental goals which exist in efficiency and consistency policy and thereby become a leading paradigm for sustainable housing.

Yet, convincing theoretical arguments and case studies will likely not suffice for sufficiency to be promoted politically. To become a popular paradigm in housing policy, sufficiency also needs to be perceived as a promising strategy by relevant stakeholders.

The purpose of this paper is to examine the degree to which the sustainability strategy 'sufficiency' has the potential to overcome the alleged trade-off between social and environmental goals in German housing policy. This paper hence evaluates whether sufficiency-according to relevant stakeholders-lives up to the theoretical claims and has the (political) potential to reconcile social and environmental goals in housing policy. After a description of the theoretical underpinnings of the sufficiency strategy in the field of housing (Sect. 2), the perspectives of relevant stakeholders from social, environmental, and housing interest groups operating at the national level in Germany are examined using Q-method (Sect. 3). The results show the stakeholders' different perspectives and highlight which sufficiency instruments are politically desired (Sect. 4). Based on these findings the paper argues how sufficiency can politically reconcile social and environmental goals of current building and housing policy in Germany (Sect. 5).

With Q-methodology not having been previously used in the field of housing policy analysis, this paper serves as the first illustration how the method can be applied in the field of housing research. It also provides the first detailed stakeholder-oriented analysis of sufficiency policies in the field of housing. The findings can be transferred to countries with a similar technical sufficiency potential such as Ireland, Luxemburg, and the Netherlands (Bierwirth and Thomas 2019) or other countries with similar 'housing-affluent' patterns to Germany. 


\section{Theory: The emergence of the sufficiency paradigm in housing policy}

The term 'sufficiency' stems from the Latin word 'sufficere', which means 'being enough'. The term 'sufficiency' was introduced 1993 into the sustainability debate by Sachs (1993) as a critique of the lacking environmental integrity of other sustainability strategies:

An ecological society needs a two-legged approach: an intelligent reduction of means and a clever restraint of goals. In other words, the "efficiency revolution" remains disoriented if it is not accompanied by a "sufficiency revolution". After all, nothing is more irrational than chasing with a maximum of efficiency in the wrong direction (own translation, Sachs 1993).

Today the doubts of the ecological success of consistency and efficiency measures continue and increasingly sustainability scientists see sufficiency as a necessary strategy in company with consistency and efficiency (Fischer and Grießhammer 2013; Bierwirth and Thomas 2019; Rijnhout et al. 2018). In contrast to technical solutions, sufficiency is defined as the modification of consumption patterns so that they support compliance with ecological sustainability (Fischer and Grießhammer 2013). It strives to do so by frugal lifestyles (Alcott 2008) and by lowering the consumption of material and energy though a reduction of demand of products and services with a high share of resources (Linz 2006). So far, sufficiency still occupies a minor position in environmental policy making. However, it starts to receive increased attention, especially in the field of energy policy (see for example Huber 2000a; Princen 2005; Barry and Doran 2006; Scherhorn 2008; Stengel 2011; Heyen et al. 2013; Lorek and Fuchs 2013; Fischer and Grießhammer 2013; Schneidewind and Zahrnt 2014; Ekardt 2016; Darby and Fawcett 2018; Spengler 2018; Rijnhout et al. 2018; Toulouse et al. 2019).

Academic research on the ecological dimension of sustainable housing has been dominated by studies on the technical aspect of sustainable housing, especially green building standards and energy efficiency programmes. Although some design approaches to housing, which can be categorized as sufficiency measures, are analysed (in this journal for example: tiny houses (Boeckermann et al. 2019) adaptability of housing space (Femenias and Geromel 2020)), and domestic floor area per capita and its downsizing is increasingly acknowledged as key leverage for environmental impact reduction (Clune et al. 2012; Welsh and Wadley 2014; Huebner and Shipworth 2017; Gröne 2018; Sandberg 2018; Shove 2018; McKinlay et al. 2019; Stieß et al. 2019; Thomas et al. 2019; Cohen 2020), only few researchers explicitly refer to the concept of sufficiency in the field of housing: Xue questions the 'decoupling strategies for sustainable housing' (Xue 2013, 2015). Schneider et al. (2012) raise the question of an 'housing overcapacity in Europe'. Nelson and Scheider (2018) provide an encompassing overview of approaches in the field. Also, Jensen et al. (2019) assess that sufficiency is yet underrepresented in sustainable energy consumption initiatives.

Recently, several architectural events and activities dealt with sufficiency or like-minded concept, for example the Oslo Architecture Triennale (2019), "Enough: The Architecture of Degrowth", a position paper of the Association of German Architects (BDA 2019), a conference at the Bauhaus-University Weimar (2019), a symposium by Friends of the Earth in Germany (BUND 2019), and a 'sufficiency award' by the German Federal Environmental Agency (UBA 2019). This suggests that sufficiency is a rising policy concept promoted by 
environmental interest group and architectural and building associations (see Sect. 5.3). Yet, it remains to be disclosed if this trend is endorsed by all stakeholders (see Sect. 5.1).

For Germany, applied research on the topic is ranging between pamphlets arguing against the need of new constructions (Fuhrhop 2015), assessments of energy and housing sufficiency potential (Brischke et al. 2016; Bierwirth and Thomas 2019; Kenkmann et al. 2019), descriptions of design options at the local level (Kopatz 2016) and casestudy review (Lorek and Spangenberg 2019). These studies and theory-based considerations suggest that sufficiency can better meet environmental goals than more technology-focussed strategies like efficiency and consistency because the 'rebound effect' is smaller or even absent (Heyen et al. 2013; Buhl 2016; for a critical perspective see Sorrell et al. 2020). In addition, sufficiency is prone to be the most social sustainability strategy as it leads to a redistribution of scarce goods from those 'over-consuming' to those 'under-consuming' (Kanschik 2016), both at the local level (e.g. fairer distribution of living space in a city) as well as on the global scale (e.g. through redistribution of construction resources (Heyen et al. 2013; Spengler 2016)). Moreover, it is argued that smaller dwelling size has positive implications on housing affordability for occupants themselves (McKinlay et al. 2019). Hence, one hypothesis to be evaluated in this paper is the positive influence of sufficiency on the perceived reconcilability of social and environmental goals (see Sect. 5.2).

How housing units are (re-) constructed and how housing is organized in society lies at the heart of a sufficiency-orientation of housing (Nelson and Scheider 2018). Bierwirth distinguishes two stages in which sufficiency in the field of housing might apply: the design phase and the use phase (Bierwirth 2015a, b). While design phase mainly refers to the architectural and planning process, use phase refers to the phase after construction and to the question how buildings are managed, occupied and used. The key goal, a reduction of demand for new construction and housing space (Lorek and Spangenberg 2019), can be reached through different approaches. Based on a review of policy proposals in the field, I identify four distinct strategies for housing sufficiency:

1. Reduction of housing space from the 'wanted' to the 'needed' amount. This takes place most vividly in the tiny house movement and, in a less symbolic way, through microapartments. It also questions the status-dimension of ample housing. Other strategies in this dimension include promoting multifunctionality of rooms, reduced flat and rooms sizes by adapted building standards as takes place in the City of Zurich, and remuneration schemes that incentivises architects and construction industry to develop space-efficient solutions. Also, functional and aesthetic longevity lower the need for demolition and new construction and hence also contribute to a reduced demand for new construction.

2. Substitution of housing needs. This signifies the (partial) substitution of the good 'housing' through another good or service without compromising the need that stands behind the initial desire for housing. For example, membership in a housing cooperative might equally protect against eviction as classical home-ownerships but allow for better adaptation to the needed number of rooms in a household. Other examples include virtual rooms, co-working spaces, cluster flats, community guest rooms, shared drying and washing rooms. The concept of sharing space though co-housing by guaranteeing access to, not ownership of, housing space is probably the most common occurrence in this dimension.

3. Flexibilization of temporal and spatial supply and demand of housing. It implies that households' housing demand is not steered by the maximum of desired (and affordable) 
housing space, resulting in oversized flats most of the times, but aims for reasonably sized flats with additional flexibility elements. These can take place at different levels of housing: At the lifespan of buildings, through temporary buildings or the reuse of existing buildings, e.g. by transformation of vacant housing units to offices or vice versa. Or at the occupation time of existing flats by the same households, by incentivising (temporary) relocation to adapt flat size to household needs. It can be encouraged through tenants' rights to sublet or swap flats as well as matching and relocation services that lower temporal and financial cost of relocations to smaller flats. Flexibility elements can occur within and between flats, like joker rooms and movable walls, which allow an easy change of floor plans and prolonging adequateness of housing for changing household circumstance.

4. Optimization of the spatial and temporal match of housing consumption. This can be reached through more efficient allocation of housing space according to housing needs. Relevant entry points are the long-term under-occupancy and the vacancy of flats between two periods of different occupation (e.g. change of tenants), of seldomly occupied flats (e.g. holiday flats), and regularly under-occupied or vacant flats (e.g. apartments of weekend-communing workers during weekdays). It can be addressed by legal instruments, like a vacancy cadastre, a minimum occupancy rule, a maximum duration of unoccupancy in areas of housing shortage and legalisation of squatting for abandoned buildings. It can as well be tackled by financial instruments, like lower tax rates for interim use of buildings, higher tax rates for holiday flats and excessive per capita space consumption in areas of housing shortage. Lastly, the challenge that housing space is predominantly distributed by ability to pay, not by housing needs, that leads to a housing mismatch in terms of over- and under-consumption of flats, can be addressed by replacing market-based by needsbased distribution schemes.

In Sect. 5.4, this paper evaluates which policy proposals of the four dimensions are most endorsed by the stakeholders.

\section{Q-Methodology}

While the detection of sustainability narratives is an established field of environmental policy research (examples using Q-method analysis are Barry and Proops 1999; Stevenson 2015), only few studies examine different narratives in housing policy with an explicit link to sustainability (Lovell 2004; Jensen and Gram-Hanssen 2008; Schneider et al. 2013; Hagbert and Femenías 2016). None of these studies targets sufficiency policy. Until now sufficiency policy has mainly been studied by environmental researchers. Therefore, little is known about its implication from other disciplines' perspectives.

In this paper, Q-methodology is applied to describe how proposed sufficiency policies in the housing sector are perceived by stakeholder from environmental, but also social and housing interest groups. The method was developed in the 1930s by William Stephenson as a variation of factor analysis (Stephenson 1935a, b). Factor analysis is a statistical method of data reduction used to explain the variation of characteristics of a population through the unveiling of latent variables ('factors'). ${ }^{1}$ The idea is that observable and measurable

\footnotetext{
${ }^{1}$ Factor analysis is usually based on the variable-by-variable correlation matrix of a sample from the population. Q-methodology on the other hand tries to find commonalities and differences between persons, not the attributes or variables. The method therefore starts with a person-by-person, and not a variable-by-variable, correlation.
} 
variables (e.g. test results) are manifestations of a smaller number of underlying determinants. Q-method analysis is well suited for the purpose of this paper because it can uncover different subjective views about a topic and is also applicable with a small sample size. It is capable of explaining the preference structure of the participants. In doing so, "Q-methodology will potentially identify a group of persons who share a similar perspective, viewpoint or attitude about a particular topic [...]" (Watts and Stenner 2012).

The method requires the standardization of an attribute in relation to all other attributes by the same person. This kind of data (Q-sorts) can only be gathered if each person compares attributes (here: in the form of verbal statement, see Table 2) with each other, and ranks them according to their subjective perspective. In practice, this is done by asking participants to rank given statements into a 'forced' distribution with a fixed number of columns and fields. Each column signifies a similar level of agreement. Based on the criteria developed by Watts and Stenner (2012), a 9-point scale $(-4$ to +4$)$ with a rather steep distribution was applied in this study.

For inherent reasons Q-method surveys need to have a balanced participant group in the sense that a broad variety of perspectives is present (Watts and Stenner 2012). Since sufficiency policy is not an established paradigm yet, the institutionalized political sphere (e.g. political parties, members of parliament, or government agencies) was not surveyed. The academic perspective, such as private or public research institutes, was also excluded as the topic of the study is not the theoretical reconcilability of social and environmental goals, but its political feasibility. Instead, the study was conducted with stakeholders from relevant interest groups in the field of housing policy, as they form the bottleneck for sufficiency to become a widely accepted political paradigm. The assumption of this approach is that new paradigms in housing policy can only emerge if they are established, promoted and lobbied for by relevant stakeholders of housing policy (for an overview of policymaking by interest groups see (Enderlein et al. 2010; Weiler and Brändli 2015)). Since this study is concerned with the reconciliation of social and environmental aims, representatives from social and environmental interest groups were added to the sample. Some of them have designated experts on housing policy (e.g. a programme officer for combating homelessness). Others, especially environmental interest group, did not have experts on housing policy. In these cases, experts for national climate policy and spatial policy were contacted. Based on a desk review scanning recent policy publications in the field, media coverage, assessment of institutional websites thirty stakeholder institutions of the national level, having at least some expertise on housing (in the case of social and environmental groups) or sustainability-orientation (for housing organizations), were identified. Within these, 21 stakeholder institutions that are most relevant and best reflect the variety of interests and perspectives in the field were contacted. 14 organizations agreed to participate, constituting 16 participants in total (Table 1). No systematic self-selection bias could be identified in this step. Using this approach, it could be ensured that the full variety of relevant perspectives in the field of sustainable housing policy is reflected in the sample. The rationale behind inclusion of key social and environmental stakeholders next to housing stakeholders is formed by the assumption that a housing strategy which claims to contribute to social and environmental goals could be promoted but also vetoed by these stakeholders. The active support by some of these stakeholders and no or little dissent within these interest groups is hence a necessary condition for a sufficiency paradigm to emerge. However, this approach does not rule out that a sustainable housing initiative by these stakeholders could be jeopardized by other interest groups (e.g. construction industry, real estate brokers, homeowner lobbies) that did not participate in the study because they do not even strive for social or environmental goals. This is likely to be the case for interest groups that have already been opposing other sustainable housing measures [e.g. the homebuilding industry in Norway 
Table 1 Participants' institutional affiliation and their factor number

\begin{tabular}{|c|c|c|c|}
\hline Institutional affiliation & Participant number & Factor number & Factor description \\
\hline Environment & $\mathrm{t} 01$ & 3 & Good housing without building \\
\hline Social & $\mathrm{t} 02$ & - & \\
\hline Environment & $\mathrm{t} 03$ & 4 & Green housing modernization \\
\hline Social & $\mathrm{t} 04$ & 1 & Social protection of the vulnerable \\
\hline Social & $\mathrm{t} 05$ & - & \\
\hline Environment & $\mathrm{t} 06$ & 4 & Green housing modernization \\
\hline Housing & $\mathrm{t} 07$ & 2 & Balance of goals \\
\hline Environment & $\mathrm{t} 08$ & 3 & Good housing without building \\
\hline Housing & $\mathrm{t} 09$ & 2 & Balance of goals \\
\hline Social & $\mathrm{t} 10$ & 1 & Social protection of the vulnerable \\
\hline Social & $\mathrm{t} 11$ & 1 & Social protection of the vulnerable \\
\hline Housing & $\mathrm{t} 12$ & 4 & Green housing modernization \\
\hline Social & $\mathrm{t} 13$ & 1 & Social protection of the vulnerable \\
\hline Social & $\mathrm{t} 14$ & 1 & Social protection of the vulnerable \\
\hline Social & $\mathrm{t} 15$ & 1 & Social protection of the vulnerable \\
\hline Housing & $\mathrm{t} 16$ & 2 & Balance of goals \\
\hline
\end{tabular}

opposing energy efficiency standards (Nykamp 2020)]. In this case a new paradigm could emerge but might not be powerful enough to translate into actual policy design.

Statements in a Q-study have to resemble the entire discourse of the topic just like the participants of a classical factor analysis have to represent the population adequately. Crucially, participants have to be able to accurately portray their subjective view through the statements. To construct the statements, a theoretical and an exploratory approach was combined. The theoretical approach is based on the conceptual analysis of the topic of sufficiency in housing: It addresses the goals and challenges of current housing policy, resting upon the theoretical categories of sustainable housing and the reconcilability of social and environmental goals as outlined above. The exploratory approach, on the other hand, was based on documents published during the three years (2014-2017) before the interview period and entails policy briefs, press releases, workshop outcomes, position papers etc. on the topic of housing policy with any focus on sustainability, particularly proposals for sufficiency in German housing policy. The two approaches were pursued in parallel, synthesised, pre-tested by two voluntary participants and finally resulted in a set of 40 statements (see Table 2$)^{2}$

\footnotetext{
${ }^{2}$ Block 1 of the items (i01-i10) resulted from the theoretical approach, the remaining statements stem from the exploratory approach. The exploratory approach was undertaken in four steps: (1) 56 topically relevant documents, like policy briefs, press releases, workshop outcomes, position papers etc. were reviewed and 334 statements were selected until the similarity of newly added statements with already included statements was very high. (2) The number of statements was reduced by deselecting statements which met at least one of the following criteria: The opposite meaning of the statement is already included in another statement; Evaluative statements of very specific or technical nature, because their ranking by the participants might less depend on the different states of mind of the participants but rather on their knowledge about current legal ruling or political decisions; Vague or indisputable statements, because participants would not form different opinions on it. (3) Statements were rephrased to enable a suitable form for Q-methodology. One risk is that the disagreement of the participants with a statement would tell little about which part of the statement they disagree with (Watts and Stenner 2012: 62). Hence, rephrasing had the goal to ensure that in case of disagreement the reasons for that could be derived. If a statement was considered very telling, but vague or indisputable, it was rephrased to make it more precise and contestable. By
} 
Table 2 Statement rank for each factor and abbreviated wording of statements

Rank of the statement for each factor

\begin{tabular}{|c|c|c|c|c|c|}
\hline $\begin{array}{c}\text { Social } \\
\text { Protection } \\
\text { of the } \\
\text { Vulnerable } \\
\text { (Factor 1) }\end{array}$ & $\begin{array}{c}\text { Balance of } \\
\text { Goals } \\
\text { (Factor 2) }\end{array}$ & $\begin{array}{c}\text { Good } \\
\text { Housing } \\
\text { without } \\
\text { Building } \\
\text { (Factor 3) }\end{array}$ & $\begin{array}{c}\text { Green } \\
\text { Housing } \\
\text { Moderni- } \\
\text { zation } \\
\text { (Factor 4) }\end{array}$ & $\begin{array}{l}\text { Statement } \\
\text { number }\end{array}$ & Statement wording (short) \\
\hline 0 & -1 & 0 & 3 & $\mathrm{i} 01$ & Key challenge environmental: efficiency \\
\hline-1 & 3 & 4 & 4 & $\mathrm{i} 02$ & Key challenge environmental: consistency \\
\hline-2 & 4 & 3 & -3 & $\mathrm{i} 03$ & Key challenge environmental: sufficiency \\
\hline 4 & 3 & -1 & 2 & $\mathrm{i} 04$ & Key challenge social: access by affordability \\
\hline 4 & 3 & 0 & -2 & i05 & Key challenge social: access by quantity \\
\hline-2 & 4 & -2 & 0 & i06 & Key challenge social: residential comfort \\
\hline-2 & 0 & -3 & -3 & i07 & Lower housing standard for affordability \\
\hline 0 & 2 & -4 & -3 & $\mathrm{i} 08$ & Enough living space before environmental targets \\
\hline 0 & 1 & 1 & 1 & i09 & High green housing standards for quality housing \\
\hline 1 & 0 & -1 & -1 & $\mathrm{i} 10$ & Housing shortage trumps environmental standards \\
\hline 2 & 2 & -3 & 0 & i11 & More developable plots to combat homelessness \\
\hline-3 & -1 & -1 & -4 & $\mathrm{i} 12$ & Consulting for 'non-building' \\
\hline-4 & 0 & -1 & 1 & i13 & Construction important for industry and employment \\
\hline-3 & -1 & -3 & -1 & i14 & More living space per person \\
\hline-2 & -3 & 4 & 0 & i15 & Only preservation of buildings in shrinking areas \\
\hline-3 & -3 & 0 & 0 & i16 & Only construction in existing contexts \\
\hline-1 & 2 & 2 & 0 & i17 & Inequality main reason for housing shortage \\
\hline 1 & -2 & 1 & -4 & i18 & Obligation to let vacant houses \\
\hline-1 & -1 & -2 & -3 & i19 & Minimum occupancy role \\
\hline-3 & -1 & -2 & -2 & i20 & Luxury tax on housing space over $40 \mathrm{qm} /$ person \\
\hline 0 & 1 & 0 & -1 & $\mathrm{i} 21$ & Ecological advantages of housing reduction \\
\hline 3 & 2 & 2 & -1 & $\mathrm{i} 22$ & Floor-efficient ground plans reduce housing shortage \\
\hline 1 & 0 & -1 & -1 & $\mathrm{i} 23$ & Reducing housing costs by compact ground-floors \\
\hline-1 & -2 & 1 & -2 & i 24 & Avoiding energy poverty by reducing housing space \\
\hline 2 & -4 & -1 & -2 & $\mathrm{i} 25$ & Support programmes for clearing out of possessions \\
\hline-4 & 0 & 0 & 1 & $\mathrm{i} 26$ & Micro-apartments prevent housing shortage \\
\hline 1 & 0 & 3 & 3 & $\mathrm{i} 27$ & Promotion of community rooms \\
\hline 2 & 1 & 3 & 1 & $\mathrm{i} 28$ & Promotion of intergenerational and co-housing \\
\hline 2 & 1 & 2 & 2 & i29 & Flexible ground plans when (re-)building \\
\hline 0 & -3 & -2 & 3 & $\mathrm{i} 30$ & Higher technical and comfort standards \\
\hline 0 & 0 & 0 & 2 & i31 & (Aesthetic) quality impacts longevity of buildings \\
\hline 1 & -1 & 1 & 4 & i32 & $\begin{array}{l}\text { Housing shortage reduces energetic retrofitting } \\
\text { incentives }\end{array}$ \\
\hline 1 & -2 & -4 & 3 & $\mathrm{i} 33$ & $\begin{array}{l}\text { Construction of family houses reduces housing } \\
\text { shortage }\end{array}$ \\
\hline 0 & 0 & 0 & 1 & i34 & $\begin{array}{l}\text { Less energy efficiency measures in owner-occupied } \\
\text { houses }\end{array}$ \\
\hline-1 & -3 & 0 & -1 & i35 & No state support for home-ownership \\
\hline-1 & -4 & 1 & 1 & $\mathrm{i} 36$ & Passive house standards for new constructions \\
\hline 0 & -2 & -4 & 0 & $\mathrm{i} 37$ & Cost-benefit ratio before ecological targets \\
\hline 3 & 3 & 2 & 2 & $\mathrm{i} 38$ & Financialization of housing sector problematic \\
\hline 3 & 1 & 0 & 0 & $\mathrm{i} 39$ & Key objective: protection of tenants \\
\hline 3 & 1 & 3 & 0 & $\mathrm{i} 40$ & $\begin{array}{l}\text { Risk of distribution of central and quality housing by } \\
\text { income }\end{array}$ \\
\hline
\end{tabular}

Footnote 2 (continued)

giving participants the opportunity to comment on the statements after locating them, unfavourable phrases would have been uncovered. An analysis of the participants' comments unveiled no major phrasing issues. (4) Due to the large number of statements a topical focus was undertaken by focussing on advocative statements about sufficiency. Finally, the statements derived from the theoretical and the explorative approach were merged. The Q-sort was pre-tested and based on this evaluation and the criteria applied in the exploratory selection process some statements were slightly rephrased and overlapping statements were reduced. This process resulted into a final set of 40 statements. The reliability of the statements is addressed through the pre-test and the comments of the participants on the statements and their Q-set. 
In the ensuing field work participants received four blocks of ten statements each. The statements of the first block were spread in front of the participants (i01-i10). The block includes statements on the main challenges of current housing policy (affordability of housing, adequateness and quality of housing, and the sustainability strategies of efficiency, consistency, and sufficiency) as well as general statements on the relationship of environmental and social goals in housing policy. In the second block (i11-i20) statements about the quantity of housing stock and its role for social and environmental goals were presented. The rating of these statement can provide information on the theoretical perception of sufficiency with housing space per person being a key indicator of sufficiency policy. The third block (i21-i30) contains concrete sufficiency related policy proposals which specify the policy design. The final block (i31-i40) includes statements of the role of property in addition to further statements on current housing policy debates. Each participant received an individual sorting sheet on which they ordered the statements according to their level of agreement (Q-sort). Afterwards, participants could comment on their Q-sort and were asked to explain the reasons for their selection. This information was used to guide the interpretation of the results.

\section{Results}

The data from the sixteen Q-sorts were statistically analysed by correlation and a by-person factor analysis. Four factors were extracted and rotated by varimax rotation. ${ }^{3}$ The results are four ideal Q-sorts. Each factor and the associated Q-sort was given a name to summarize the viewpoint. Together the four factors explain 67.28 percent of the study variance. 14 of the 16 Q-sorts load significantly on at least one of the four factors. The Q-sorts which load significantly on more than one factor were attributed to the factor they are most associated with (see Table 1). Q-sorts that load significantly on the same factor exhibit a common sorting pattern: The respective participants ranked the statement in a similar way because they hold similar beliefs about the issue at hand (see Table 2). The result was interpreted for each factor as follows:

\subsection{Factor 1: Social Protection of the Vulnerable}

The highest ranked statements of Factor 1 all concern social aspects of housing and all participants whose Q-sort is associated with this factor belong to social interest groups. Avoiding homelessness and gentrification is their key priority. Participants care less about the way in which these social goals are met, for instance due to an increase of available housing space, protecting tenants, or keeping the costs of housing low to make housing affordable for low-income groups. In general, they seem to fear that other policy goals, such as the interests of the construction sector and environmental goals, compete with the goals of reducing homelessness. Furthermore, the impression that the needs of the poor are not enough represented in the way new buildings are constructed prevails: space efficient floor plans are particularly endorsed, and they disagree that 'successful housing' signifies

\footnotetext{
3 For this purpose, factor scores and ranks were calculated. A statement's factor score is the normalised weighted average statement score (Z-score) of Q-sorts that define that factor. These factor scores are translated for each factor in a typical rank of each statement in the sorting sheet (Table 1). The Q-sort of one factor shows how a hypothetical participant with a 100 percent loading on that factor would have ordered the statements.
} 
more floor space. This group prioritises social over environmental considerations and finds increasing building activity a helpful but not sufficient strategy for meeting these targets.

\subsection{Factor 2: Balance of Goals}

All of the associated Q-sorts of Factor 2 belong to representatives from housing institutions. The group puts more emphasis on the description of problems and is more confident about what the long-term strategies should be in housing policy than what this means for today's political decisions. This group does not have an exclusive interest in social or environmental aspects of housing but is more concerned with balancing these goals. Consequently, they are satisfied with the ecologically second-best solution. They also highlight the trade-offs between social and environmental goals. Too high and rigid standards in housing, they argue, risk cost-effectiveness, which should be a central aim, especially in apartment buildings. It is easier for them to agree on the current state of housing policy then on what should be done to meet its challenges. This is illustrated by their ambivalent position towards single-family homes. While they acknowledge that single-family houses are undesirable from an ecological point of view, they also describe single family houses as a social accomplishment. At the same time, a reduction of living space is seen as fruitful because it may entice architects and housing support schemes to find smart and innovative solutions. In general, this group prefers taxation, market mechanism and incentives over strict regulations. Contrary to group 4, technical solutions are not most promising to them. Rather, they prioritize non-radical but longterm planning for smart and creative solutions.

\subsection{Factor 3: Good housing without building}

Environmental stakeholders are split into two groups (Factor 3 and Factor 4). The group of Factor 3 emphasises sufficiency as a solution to both social and environmental problems. These participants care a lot about environmental goals, in particular about land consumption. They strongly advocate the sustainability strategies of consistency and sufficiency, but less so efficiency. Furthermore, they strongly oppose the idea that environmental goals should be downgraded in favour of economic concerns or, crucially, social goals. Interestingly, they do not think so because they place environmental goals over social goals (as present in Factor 4), but because they are convinced that it is not necessary to abandon environmental goals for social reasons. Compared to the other groups there is a particularly strong awareness of the financialization of the housing sector and property-owning regimes towards which they are sceptical. They are also more aware of the distributional aspects on housing. According to them, housing demand should not be met by more construction but instead be questioned. Moreover, they believe existing space should be used more efficiently. Similar to Factor 2 this group cares about both environmental and social goals, but contrary to group 2 is much more open to a stricter regulatory approach. Concerning the favoured strategies, they clearly advocate sufficiency as a strategy to reconcile social and environmental goals. 


\subsection{Factor 4: Green housing modernization}

Factor 4 represents the other half of environmental stakeholders. They predominantly see the best way to achieve environmental goals in technological solutions and are less concerned about social issues than group 3. For this group environmental aspects are clearly the top priority, particularly the strategies of efficiency and consistency. They want to see high standards implemented to modernize buildings and ponder adequate market incentives to achieve this. Contrary to Factor 3, they do not take a critical position towards housing property and markets but rather endorse stable property rights as incentives for ecological modernization. This is related to the conviction that the state is not supposed to interfere with private standards of living. Since sufficiency seeks to change the consumption behaviour of individuals, they rather disapprove such policies, apart from the introduction of new products like micro-apartments. More than any other group they emphasize the role of the building sector as a provider of employment. In summary, this factor resembles the discourse of environmental modernization, which prioritizes technological progress to combat environmental problems over other environmental strategies as well as social goals.

\section{Discussion}

Drawing participants from the three groups of social, environmental, and housing stakeholders would indicate three factors to emerge. Instead, four factors were extracted. The participants from environmental interest groups are split into Factor 3 'Good Housing without Building' and factor 4 'Green Housing Modernization'. This distinction resembles the division between 'Degrowth' and 'Green Growth' in the general sustainability discourse (e.g. Bauhardt 2014; Stevenson 2015). The housing sectors position is not simply a compromise between social and environmental interest groups, but all four groups form inherently distinct positions.

\subsection{Commonalities of the different factors}

Although the groups hold different viewpoints, there is consensus on some issues, particularly the description of social problems. Participants agree that there is a risk of gentrification, that the financialization of the real estate sector implies that housing is increasingly built and acquired as an investment rather than to satisfy residents' needs, and that keeping housing affordable is a great challenge. Participants neither contest the importance of energy-efficiency in housing nor believe that overall more housing space is needed. They agree to endorse the sufficiency measure 'prioritising intergenerational building groups and community housing' and they agree to reject the sufficiency measure 'prescribe minimum occupancy rules'.

\subsection{Overcoming trade-offs through sufficiency}

Broadly speaking, no serious trade-off between social and environmental goals is articulated by the participants. Efficiency and consistency measures are described as rather compatible with social goals like adequate and affordable housing in technical and 
political terms. At most social interest groups (Factor 1) emphasize the risk of a political trade-off and fear that environmental aspects might crowd out social aspects of the housing agenda. The largest disagreement exists about the potential trade-off between a reduction of land-use and resource consumption on the one hand and adequate availability of housing on the other hand. Group 3 (Good Housing without Building) sees the lowest trade-off between social and environmental goals. This supports the hypothesis that if participants see no trade-off between environmental and social goals, they do so because of sufficiency as a reconciling strategy. Still, there is no consensus yet between all groups on a synergy of social goals and land-use reduction through sufficiency. The following questions, on whether new constructions should take place or not, are among the most contested: Should only existing buildings and their preservation be supported in shrinking areas (i15)? Do we need more housing space to prevent homelessness (i11)? Is enough housing for all just a question of fair distribution (i17)?

While group 3 has a clear sufficiency orientation, the others disagree with some measures of sufficiency policy in one form or another. However, none of the detected discourses formulates general objections against sufficiency. Rather, different sufficiency policies are rejected by different groups for different reasons. The analysis of the statements which distinguish the positions in this light reveals that the opposition against sufficiency is mainly rooted in a lack of knowledge about sufficiency (for Factor 2 ), combined with a one-sided regard of either social or environmental goals (Factor 1 and Factor 4).

\subsection{Sufficiency as a new paradigm in housing policy}

The low sufficiency concern of group 4 is mainly due to a narrow consideration of only technical solutions and the disregard of the environmental impacts of land use consumption. A similarly narrow concentration of group 1 on social matters explains their indifference towards environmental goals. Surprisingly, the role of sufficiency as a distributional policy is not acknowledged by this group, as they see their role more in compensating for unsocial market outcomes than in putting fair market effects into practice. The re-politicization of social interest groups concerned with inequality could promote sufficiency as a strategy, not only for environmental but also for social reasons. This development depends on the availability of information about the social impact of sufficiency. In particular, a quantitative study on the distributional effects of sufficiency policy and its implications for poverty prevention is lacking. This establishes a promising new research field for both sustainability research as well as social policy research taking up the recent developments of inequality research.

Stakeholders from groups 2 and 3 could be key actors in advancing the sufficiency debate. Group 3 is an explicit sufficiency advocate while group 2 has a positive but reticent attitude towards sufficiency. Just like group 3, housing institutions (group 2) care about social and environmental goals and advocate sufficiency on the conceptual level. However, they are more sceptical about how housing availability and low land use consumption can be brought together. Together, the two discourses could underpin an attractive and feasible yet still effective sufficiency policy. The fact that precisely the two groups that integrate social and environmental goals in their considerations favour the idea of sufficiency policy makes for a rather optimistic outlook for its future implementation. 
However, one noteworthy limitation is the power of other lobby groups that are willing to sacrifice advances in sustainable housing for their economic interest, as has for example been the case for the US' homebuilding industry opposing energy codes (Shapiro 2016). Nonetheless, with a diligent strategic approach and under circumstance of high political pressure to reduce negative environmental impact of the housing sector, sufficiency still has a good chance to become a leading paradigm for reconciling social and environmental goals, not only as far as conceptual aspects of sustainable housing are concerned, but also in political practice.

\subsection{Promising applications of sufficiency in housing}

Still, sufficiency is not a major paradigm in German housing policy yet. The results of the analysis also show which concrete policy proposals are most promising to further the advocacy of sufficiency, because they are both transformative and endorsed by the interviewed stakeholders:

1. The current tendency in housing is the construction of eco-efficient buildings. Sufficiency policy could seek to transform this trend from 'owning green' to 'having less'. The tiny house movement is an example for a new trend towards the reduction of living space (Sandberg 2018; Mangold and Zschau 2019). Such movements could be supported by an innovation policy which honours smart design rather than new technology, like space-efficient floor plans or concepts which allow an easy alteration of ground plans. Today, housing programmes in Germany are still focussed on financing technical innovation. Instead, support programmes could incentivise efficient consumption per person rather than object (e.g. energy consumption of a building per inhabitant, not per square metre (Bierwirth and Thomas 2019)).

2. Another obstacle for the adaptation of housing consumption to the actual needs is home ownership since it makes relocation costlier. Abolishing incentives for home ownership and housing as an investment would therefore be a key task of sufficiency policy. Community housing as an established sufficiency policy of substituting the possession of individual flats with access to shared housing space enjoys unreserved popularity with the study participants. This could serve as a starting point for the development and advancement of alternatives to home ownership in both theoretical research and the development of workable business models (Nelson and Scheider 2018).

3. Another promising approach is the reduction of the housing space of individuals to what is actually wanted and needed. One particularly promising target group for this reduction are people who live in flats that have become too large for their current life situation. The elderly, in particular, might often desire to exchange obsolete quantity for higher quality of housing (e.g. barrier-free housing) yet they stay put in their current flats for economic reasons (Sorrell et al. 2020). Allowing tenants to swap flats without loosing the rental caps of long-lasting contracts could help to match housing needs better with the current stock and make some new construction obsolete.

4. The bottleneck for the emergence of a sufficiency paradigm in housing will be the discovery of the distributional aspect of sufficiency policy. Currently social interest groups (Factor 1) display only a narrow understanding of their mandate: In particular, they do not consider housing as a field of distributional justice. Neither do they perceive housing as a positional good. Instead, housing, is misconceptualized as a good of which society can simply produce more if some people have not enough of it. A redistribution of hous- 
ing space in housing-affluent countries like Germany (Bierwirth and Thomas 2019), however, could unify social and environmental targets. This can be reached through a graduated property taxation (Cohen 2019), particularly when adjusted for per-capita housing space (Bohnenberger 2020). This issue could be highlighted by a sufficiency policy which raising the awareness of 'spatial justice'.

\section{Conclusion}

This article showed that under certain terms a policy of sufficiency has the political potential to reconcile social and environmental goals in German housing policy. The Q-methodological study revealed four factors representing the stakeholders' perspectives. The academic split between Green Growth and Degrowth was discovered to be also present in housing policy and to divide German environmental stakeholders as concerns housing policy (Factor 3 and Factor 4). Some of the environmental groups (Factor 3) are outspoken advocates of sufficiency in housing policy. Together with the stakeholders from housing institutions (Factor 2), they could form a promising coalition for sufficiency. Both groups seek to reconcile environmental and social goals, and both see sufficiency as a promising strategy for this purpose. None of the interviewed groups is generally opposed to the concept of sufficiency but most hesitate about one or another policy measure it might include. All in all, more knowledge and best practices about sufficiency approaches need to be developed and disseminated. Based on this, stakeholders from housing organizations and some environmental groups could form a coalition and establish sufficiency as a new political paradigm in German housing policy.

Acknowledgments Open Access funding provided by Projekt DEAL. I would like to thank Frank Nullmeier and Sebastian Haunss for their motivating guidance, Max Held for generously sharing his technical expertise of Q-Methodology, Miriam Rehm, Jan Nill and anonymous reviewers for valuable feedback on earlier versions of this article.

Funding This research received no specific grant from any funding agency in the public, commercial, or not-for-profit sectors.

\section{Compliance with ethical standards}

Conflict of interest No potential conflict of interest was reported by the author.

Open Access This article is licensed under a Creative Commons Attribution 4.0 International License, which permits use, sharing, adaptation, distribution and reproduction in any medium or format, as long as you give appropriate credit to the original author(s) and the source, provide a link to the Creative Commons licence, and indicate if changes were made. The images or other third party material in this article are included in the article's Creative Commons licence, unless indicated otherwise in a credit line to the material. If material is not included in the article's Creative Commons licence and your intended use is not permitted by statutory regulation or exceeds the permitted use, you will need to obtain permission directly from the copyright holder. To view a copy of this licence, visit http://creativecommons.org/licenses/by/4.0/.

\section{References}

Alcott, B. (2008). The sufficiency strategy: Would rich-world frugality lower environmental impact? Ecological Economics, 64(4), 770-786. 
Barry, J., \& Doran, P. (2006). Refining green political economy: From ecological modernisation to economic security and sufficiency. Analyse \& Kritik, 28(2), 250-275.

Barry, J., \& Proops, J. (1999). Seeking sustainability discourses with Q methodology. Ecological Economics, 28(3), 337-345.

Bauhardt, C. (2014). Solutions to the crisis? The Green New Deal, Degrowth, and the Solidarity Economy: Alternatives to the capitalist growth economy from an ecofeminist economics perspective. Ecological Economics, 102, 60-68.

Bauhaus-University Weimar (2019). Postwachstumsstadt: Perspektiven des sozial-ökologischen Wandels der Stadtgesellschaft. Conference at Bauhaus-University Weimar. May 2019. http://postwachstumsst adt.de/.

BDA (2019). Das Haus der Erde. Position paper Bund deutscher Architekten. https://www.db-bauzeitung .de/wp-content/uploads/B/D/BDA-Positionspapier_Das-Haus-der-Erde.pdf.

Bierwirth, A. (2015). Suffizienz im Bauen und Nutzen von Gebäuden: Wie kann „weniger"gefördert werden? Paper presented at co2online Fachtagung ,wirksam sanieren“. Workshop $25^{\text {th }}$ March 2015.

Bierwirth, A., \& Thomas, S. (2015). Almost best friends: sufficiency and efficiency. Can sufficiency maximise efficiency gains in buildings? Eceee summer study proceedings.

Bierwirth, A., \& Thomas, S. (2019). Energy sufficiency in buildings. Concept paper. Energy Sufficiency project report. https://www.energysufficiency.org/libraryresources/library/items/energy-sufficiency-inbuildings-concept-paper.

Boeckermann, L. M., Kaczynski, A. T., \& King, S. B. (2019). Dreaming big and living small: Examining motivations and satisfaction in tiny house living. Journal of Housing and the Built Environment, 34(1), 61-71.

Bohnenberger, K. (2020). Money, Vouchers, Public Infrastructures? A Framework for Sustainable Welfare Benefits. Sustainability, 12(2), 596.

Bouzarovski, S., Frankowski, J., \& Herrero, S. T. (2018). Low-carbon gentrification: When climate change encounters residential displacement. International Journal of Urban and Regional Research, 42(5), $845-863$.

Brischke, L. A., Leuser, L., Duscha, M., Thomas, S., Thema, J., Spitzner, M., Kopatz, M., Baedeker, C., Lahusen, M., Ekardt, F., \& Beeh, M. (2016). Energiesuffizienz-Strategien und Instrumente für eine technische, systemische und kulturelle Transformation zur nachhaltigen Begrenzung des Energiebedarfs im Konsumfeld Bauen/Wohnen. Project report. Heidelberg: ifeu-Institut für Energie- und Umweltforschung. https://energiesuffizienz.files.wordpress.com/2016/12/energiesuffizienz_endbericht .pdf.

Brown, T., \& Bhatti, M. (2003). Whatever happened to 'Housing and the Environment'? Housing Studies, $18(4), 505-515$.

Buhl, J. (2016). Indirect effects from resource sufficiency behaviour in Germany. In T. Santarius (Ed.), Rethinking climate and energy policies (pp. 37-54). Cham: Springer.

BUND (2019). Suffizientes Wohnen statt Flächenverbrauch-Wege zu einem nachhaltigen Wohnflächenmanagement. Symposium organised by BUND für Naturschutz und Umwelt in Deutschland (Friends of the Earth Germany). March 2019. https://www.bund-hamburg.de/themen/umweltpolitik/flaechensc hutz/fachtagung-suffizientes-wohnen-2019/

Chan, A. P. C., \& Adabre, M. A. (2019). Bridging the gap between sustainable housing and affordable housing: The required critical success criteria (CSC). Building and Environment, 151, 112-125.

Choguill, C. L. (2007). The search for policies to support sustainable housing. Habitat International, 31, $143-149$.

Clune, S., Morrissey, J., \& Moore, T. (2012). Size matters: House size and thermal efficiency as policy strategies to reduce net emissions of new developments. Energy Policy, 48, 657-667.

Cohen, M. J. (2019). Reforming local public finance to reduce resource consumption: The sustainability case for graduated property taxation. Sustainability Science, 14(2), 289-301.

Cohen, M. J. (2020). New conceptions of sufficient home size in high-income countries: Are we approaching a sustainable consumption transition? Housing, Theory and Society. https://doi.org/10.1080/14036 096.2020.1722218.

Darby, S., \& Fawcett, T. (2018). Energy sufficiency: An introduction. Concept paper. Energy Sufficiency project report. https://www.energysufficiency.org/static/media/uploads/site-8/library/papers/sufficienc y-introduction-final-oct2018.pdf.

Dempsey, N., Bramley, G., Power, S., \& Brown, C. (2011). The social dimension of sustainable development: Defining urban social sustainability. Sustainable Development, 19(5), 289-300.

Dixon, T., \& Woodcraft, S. (2013). Creating strong communities-measuring social sustainability in new housing development. Town \& Country Planning, 82(11), 473-480. 
Eizenberg, E., \& Jabareen, Y. (2017). Social sustainability: A new conceptual framework. Sustainability, $9(1), 68$.

Ekardt, F. (2016). Theorie der Nachhaltigkeit. Baden-Baden: Nomos.

Ellsworth-Krebs, K. (2020). Implications of declining household sizes and expectations of home comfort for domestic energy demand. Nature Energy, 5(1), 20-25.

Enderlein, H., Wälti, S., \& Zürn, M. (2010). Handbook on multi-level governance. Cheltenham: Edward Elgar Publishing.

Femenias, P., \& Geromel, F. (2020). Adaptable housing? A quantitative study of contemporary apartment layouts that have been rearranged by end-users. Journal of Housing and the Built Environment, 35, 481-505.

Fischer, C., \& Grießhammer, R. (2013). When less is more: Sufficiency: Terminology, rationale and potentials. Öko-Institut Working Paper, 2 (2013). https://www.oeko.de/oekodoc/1879/2013-007-en.pdf.

Fuhrhop, D. (2015). Verbietet das Bauen! Eine Streitschrift. München: Oekom.

Gröne, M.-C. (2018). Energiesuffizienz in der Stadtentwicklung: Akteure-Strategien-Szenarien. München: Oekom.

Hagbert, P., \& Femenías, P. (2016). Sustainable homes, or simply energy-efficient buildings? Journal of Housing and the Built Environment, 31, 1-17.

Hagbert, P., \& Malmqvist, T. (2019). Actors in transition: Shifting roles in Swedish sustainable housing development. Journal of Housing and the Built Environment, 34, 697-714.

Heyen, D. A., Fischer, C., Barth, R., et al. (2013). Mehr als nur weniger: Suffizienz: Notwendigkeit und Optionen politischer Gestaltung. Öko-Institut Working Paper, 3(2013). https://www.oeko.de/oekod oc/1837/2013-506-de.pdf.

Huber, J. (2000a). Industrielle Ökologie. Konsistenz, Effizienz und Suffizienz in zyklusanalytischer Betrachtung. In: Simonis. U.E. (Ed.), Global Change. Baden-Baden: Nomos.

Huber, J. (2000b). Towards industrial ecology: Sustainable development as a concept of ecological modernization. Journal of Environmental Policy \& Planning, 2(4), 269-285.

Huebner, G. M., \& Shipworth, D. (2017). All about size? The potential of downsizing in reducing energy demand. Applied Energy, 186(2), 226-233.

Jensen, C. L., Goggins, G., Røpke, I., \& Fahy, F. (2019). Achieving sustainability transitions in residential energy use across Europe: The importance of problem framings. Energy Policy, 133, 110927.

Jensen, J. O., \& Gram-Hanssen, K. (2008). Ecological modernization of sustainable buildings: A Danish perspective. Building Research \& Information, 36, 146-158.

Kanschik, P. (2016). Eco-sufficiency and distributive sufficientarianism-Friends or foes? Environmental Values, 25(5), 553-571.

Kenkmann, T., Cludius, J., Fischer, C., Fries, T., Keimeyer, F., Schumacher, K., \& Brischke, L.-A. (2019). Flächensparend Wohnen: Energieeinsparung durch Suffizienzpolitiken im Handlungsfeld „,Wohnfläche“. TEXTE 104/2019. Dessau: Umweltbundesamt.

Kopatz, M. (2016). Kommunale Suffizienzpolitik. Strategische Perspektiven für Städte, Länder und Bund. BUND Paper. Wuppertal: Wuppertal Institut. https://epub.wupperinst.org/frontdoor/index/index/docId $/ 6405$

Korhonen, J., Honkasalo, A., \& Seppälä, J. (2018). Circular economy: The concept and its limitations. Ecological Economics, 143, 37-46.

Krausmann, F., Wiedenhofer, D., \& Haberl, H. (2020). Growing stocks of buildings, infrastructures and machinery as key challenge for compliance with climate targets. Global Environmental Change, 61, 102034.

Linz, M. (2006). Was wird dann aus der Wirtschaft? Über Suffizienz, Wirtschaftswachstum und Arbeitslosigkeit. Wuppertal Papers, 157. https://nbn-resolving.org/urn:nbn:de:101:1-200911101798.

Lorek, S., \& Fuchs, D. (2013). Strong sustainable consumption governance-Precondition for a degrowth path? Journal of Cleaner Production, 38, 36-43.

Lorek, S., \& Spangenberg, J. H. (2019). Energy sufficiency through social innovation in housing. Energy Policy, 126, 287-294.

Lovell, H. (2004). Framing sustainable housing as a solution to climate change. Journal of Environmental Policy \& Planning, 6, 35-55.

Mangold, S., \& Zschau, T. (2019). In search of the "Good Life": The appeal of the tiny house lifestyle in the USA. Social Sciences, 8(1), 26.

McKinlay, A., Baldwin, C., \& Stevens, N. J. (2019). Size matters: Dwelling size as a critical factor for sustainable urban development. Urban Policy and Research, 37(2), 135-150.

Muller, A., \& Schader, C. (2017). Efficiency, sufficiency, and consistency for sustainable healthy food. The Lancet Planetary Health, 1(1), e13-e14. 
Muñiz, I., Calatayud, D., \& Dobaño, R. (2013). The compensation hypothesis in Barcelona measured through the ecological footprint of mobility and housing. Landscape and Urban Planning, 113, 113-119.

Nelson, A., \& Scheider, F. (2018). Housing for degrowth: Principles, models, challenges and opportunities, routledge environmental humanities. London: Routledge.

Nykamp, H. (2020). Policy mix for a transition to sustainability: Green buildings in norway. Sustainability, 12(2), 446.

Oslo Architecture Triennale (2019). Enough: The Architecture of Degrowth. http://oslotriennale.no/en/about oat 2019 .

Parrique, T., Barth, J., Briens, F., Kerschner, C., Kraus-Polk, A., \& Kuokkanen, A. (2019). Decoupling debunked: Evidence and arguments against green growth as a sole strategy for sustainability. Brussels: European Environmental Bureau.

Poruschi, L., \& Ambrey, C. L. (2018). Densification, what does it mean for fuel poverty and energy justice? An empirical analysis. Energy Policy, 117, 208-217.

Princen, T. (2005). The logic of sufficiency. Cambridge: MIT Press.

Rahlf, T. (2015). Dokumentation zum Zeitreihendatensatz für Deutschland 1834-2012. Historical Social Research, http://dx.doi.org/10.12759/hsr.trans.26.v01.2015.

Rijnhout, L., Mastini, R., Potocnik, J., Spangenberg, J., Alcott, B., Kiss, V., et al. (2018). Sufficiency-Moving beyond the gospel of eco-efficiency. Brussels: Friends of the Earth Europe.

Röck, M., Saade, M. R. M., Balouktsi, M., Rasmussen, F. N., Birgisdottir, H., Frischknecht, R., et al. (2020). Embodied GHG emissions of buildings-The hidden challenge for effective climate change mitigation. Applied Energy, 258, 114107.

Rufat, S., \& Marcińczak, S. (2020). The equalising mirage? Socioeconomic segregation and environmental justice in post-socialist Bucharest. Journal of Housing and the Built Environment, 10, 1-12. https://doi.org/10.1007/s10901-019-09722-7.

Sachs, W. (1993). Die vier E's: Merkposten für einen maßvollen Wirtschaftsstil. Politische ökologie, 11(33), 69-72.

Samadi, S., Gröne, M.-C., Schneidewind, U., Luhmann, H.-J., Venjakob, J., \& Best, B. (2017). Sufficiency in energy scenario studies: Taking the potential benefits of lifestyle changes into account. Technological Forecasting and Social Change, 124, 126-134.

Sandberg, M. (2018). Downsizing of housing: Negotiating sufficiency and spatial norms. Journal of Macromarketing, 38(2), 154-167.

Schäpke, N., \& Rauschmayer, F. (2014). Going beyond efficiency: Including altruistic motives in behavioral models for sustainability transitions to address sufficiency. Sustainability Science, Practice and Policy, 10(1), 29-44.

Scherhorn, G. (2008). Über Effizienz hinaus. In S. Hartard, S. Schaffer, \& A. Giegrich (Eds.), Ressourceneffizienz im Kontext der Nachhaltigkeitsdebatte. Nomos: Baden-Baden.

Schneider, F., Asara, V., \& Sekulova, F., et al. (2013). Sustainable housing in a post-growth Europe. Working Paper Project Responder; Linking SCP and Growth Debates www.SCP-RESPONDER.eu.

Schneider, F., Scholl, G., \& Gaetaniello, A. (2012). Background paper on sustainable housing and growth. Presented at 1st Multinational knowledge brokerage event on Sustainable Housing, Barcelona, 28- 30 March 2012, RESPONDER FP7 Grant Agreement number 265297.

Schneidewind, U., \& Zahrnt, A. (2014). The politics of sufficiency. München: Oekom.

Shapiro, S. (2016). The realpolitik of building codes: Overcoming practical limitations to climate resilience. Building Research \& Information, 44(5-6), 490-506.

Shove, E. (2018). What is wrong with energy efficiency? Building Research \& Information, 46(7), 779-789.

Smets, P., \& van Lindert, P. (2016). Sustainable housing and the urban poor. International Journal of Urban Sustainable Development, 8(1), 1-9.

Sorrell, S., Gatersleben, B., \& Druckman, A. (2020). The limits of energy sufficiency: A review of the evidence for rebound effects and negative spillovers from behavioural change. Energy Research \& Social Science, 64, 101439.

Sovacool, B. K. (2015). Fuel poverty, affordability, and energy justice in England: Policy insights from the Warm Front Program. Energy, 93, 361-371.

Spengler, L. (2016). Two types of 'enough': Sufficiency as minimum and maximum. Environmental Politics, 25(5), 921-940.

Spengler, L. (2018). Sufficiency as policy. Baden-Baden: Nomos.

Stengel, O. (2011). Weniger ist schwer: Barrieren in der Umsetzung suffizienter Lebensstile-Und wie wir sie überwinden können. Gaia, 20, 26-30. 
Stephan, A., \& Crawford, R. H. (2016). The relationship between house size and life cycle energy demand: Implications for energy efficiency regulations for buildings. Energy, 116, 1158-1171.

Stephenson, W. (1935a). Correlating persons instead of tests. Journal of Personality, 4(1), 17-34.

Stephenson, W. (1935b). Technique of factor analysis. Nature, 136, 297. https://doi.org/10.1038/136297b0.

Stevenson, H. (2015). Contemporary discourses of green political economy: A Q method analysis. Journal of Environmental Policy \& Planning, 21(5), 533-548.

Stieß, I., Umbach-Daniel, A., \& Fischer, C. (2019). Smart small living? Social innovations for saving energy in senior citizens' households by reducing living space. Energy Policy, 133, 110906.

Thomas, S., Thema, J., Brischke, L.-A., Leuser, L., Kopatz, M., \& Spitzner, M. (2019). Energy sufficiency policy for residential electricity use and per-capita dwelling size. Energy Efficiency, 12(5), 1123-1149.

Toulouse, E., Sahakian, M., Lorek, S., Bohnenberger, K., Bierwirth, A., Leuser, L. (2019). Energy sufficiency: How can research better help and inform policy-making? eceee summer study proceedings.

UBA. (2019). Sonderpreis Nachhaltigkeit und Innovation. Umweltbundesamt. https://www.umweltbund esamt.de/sonderpreis-nachhaltigkeit-innovation. Accessed 11 Mar 2020.

Viggers, H., Keall, M., Wickens, K., \& Howden-Chapman, P. (2017). Increased house size can cancel out the effect of improved insulation on overall heating energy requirements. Energy Policy, 107, 248-257.

Watts, S., \& Stenner, P. (2012). Doing Q methodological research: Theory, method and interpretation. London: Sage Publications.

WCED. (1987). Our common future: Report of the world commission on environment and development. Oxford: Oxford University Press.

Weiler, F., \& Brändli, M. (2015). Inside versus outside lobbying: How the institutional framework shapes the lobbying behaviour of interest groups: Inside versus outside lobbying. European Journal of Political Research, 54(4), 745-766.

Welsh, A., \& Wadley, D. (2014). The relationship of dwelling size and population potential: Practical implications for strategic urban planning. Urban Policy and Research, 32(1), 85-105.

Wickes, R., Zahnow, R., Corcoran, J., \& Hipp, J. R. (2019). Neighbourhood social conduits and resident social cohesion. Urban Studies, 56(1), 226-248.

Wilson, A., \& Boehland, J. (2008). Small is beautiful US house size, resource use, and the environment. Journal of Industrial Ecology, 9(1-2), 277-287.

Winston, N., \& Pareja Eastaway, M. (2008). Sustainable housing in the urban context: International sustainable development indicator sets and housing. Social Indicators Research, 87(2), 211-221.

Xue, J. (2012). Indicators of decoupling housing-related environmental impacts from economic growth. Journal of Housing and the Built Environment, 27(4), 495-516.

Xue, J. (2013). Economic growth and sustainable housing: An uneasy relationship. London: Routledge.

Xue, J. (2015). Sustainable housing development: Decoupling or degrowth? A comparative study of Copenhagen and Hangzhou. Environment and Planning C: Government and Policy, 33(3), 620-639.

Publisher's Note Springer Nature remains neutral with regard to jurisdictional claims in published maps and institutional affiliations. 